\title{
Preparation of High Specific Surface Area Micro/Meso-porous SiOC Ceramics by the Low Temperature Phase Separation Method
}

\author{
LI Jia-Ke, HAN Xiao-Qi, LIU Xin, WANG Yan-Xiang, GUO Ping-Chun, YANG Zhi-Sheng \\ (School of Materials Science and Engineering, Jingdezhen Ceramic Institute, Jingdezhen 333403, China)
}

\begin{abstract}
Micro/meso-porous SiOC ceramics with high surface area and narrow pore size distribution were prepared by the low temperature phase separation method (namely water vapor assisted pyrolysis) followed by etching in hydrofluoric acid (HF) solution. The cross-linked body was made from hydrogen-containing polysiloxane (PHMS), tetramethyl-tetravinylcycletetrasiloxane $\left(\mathrm{D}_{4}^{\mathrm{vi}}\right)$ and Pt-complex by thermal cross-linking. Phase compositions, chemical bonds, microstructures, and specific surface area of the prepared SiOC ceramic were investigated by XRD, FT-IR, SEM, and BET, etc. Water vapor can promote the precursor to produce $\mathrm{Si}-\mathrm{O}-\mathrm{Si}$ bonds, $\mathrm{SiO}_{2}$-rich clusters, and $\mathrm{SiO}_{2}$ nanocrystals in SiOC ceramics. All of these species act as pore-forming substrate and can be etched away by HF. Water vapor injection and pyrolysis temperature have important effects on phase compositions, microstructures and specific surface area of SiOC porous ceramics, which have a maximum specific surface area of $1845.5 \mathrm{~m}^{2} / \mathrm{g}$ and pore size distribution of $2.0^{-10} \mathrm{~nm}$ at pyrolysis temperature of $1300^{\circ} \mathrm{C}$.
\end{abstract}

Key words: micro/meso-porous SiOC; low temperature phase separation; phase composition; microstructure; etching

In recent years, porous $\mathrm{SiOC}$ ceramics have attracted a lot of interest due to their higher specific surface area, thermal stability and good electric conductivity. They have wide application potentials in the field of catalyst support, solar cells, solid oxygen fuel cells, and super capacitors, etc. ${ }^{[1-2]}$

Various strategies have been used to prepare porous SiOC materials from polymers, including replica ${ }^{[3]}$, sacrificial template ${ }^{[4]}$, direct foaming ${ }^{[5]}$, reactions ${ }^{[6]}$, and high temperature phase separation ${ }^{[7]}$. Out of these approaches, only SiOC porous ceramic prepared by high temperature phase separation can offer uniform micro-/meso-pore sizes, large pore volumes, and higher specific surface area.

High temperature phase separation can occur during pyrolysis above $1200^{\circ} \mathrm{C}$ and produce $\mathrm{SiO}_{2}$ nanodomains, $\mathrm{SiC}$, and free carbon. The $\mathrm{SiO}_{2}$ nanodomains may be eliminated by $\mathrm{HF}$, so the pores are left behind by $\mathrm{SiO}_{2}$ nanodomains ${ }^{[8-9]}$. Due to carbothermal reaction is accompanied by high temperature phase separation reaction during pyrolysis ${ }^{[10-11]}$, and it consumes $\mathrm{SiO}_{2}$ nanodomains and free carbon $\left(\mathrm{SiO}_{2(\mathrm{~s})}+\mathrm{C}_{(\mathrm{s})} \rightarrow \mathrm{SiO}_{(\mathrm{g})}+\mathrm{CO}_{(\mathrm{g})}\right)$ which are produced from high temperature phase separation, and the rate of carbothermal reaction will be accelerated with the increase of pyrolysis temperature, thus carbothermal reaction will hinder further increase of specific surface area of SiOC. In order to prevent or decrease carbothermal reaction, some researchers have done a lot of work. Main study focuses on the adjustment of batch formula or adding dopants ${ }^{[9,12]}$.

In this work, a versatile method, water vapor assisted pyrolysis, is used to promote phase separation of the precursor at a low temperature (below $1000^{\circ} \mathrm{C}$ ). Porous SiOC ceramics with micro-/meso-pore sizes are prepared with $\mathrm{HF}$ etching for SiOC ceramics. Effects of water vapor and pyrolysis temperature on SiOC ceramic phase compositions, chemical bonds, microstructures and porosity are investigated before and after etching.

\section{Experimental}

\subsection{Preparation of samples}

Commercially available hydrogen-containing polysiloxane (PHMS) was used as the preceramic polymer, tetramethyltetravinylcycletetrasiloxane $\left(\mathrm{D}_{4}{ }^{\mathrm{Vi}}\right)$ as the cross-linking agent and Pt- complex as catalyst. PHMS and $\mathrm{D}_{4}{ }^{\mathrm{Vi}}$ (mass ratio $2: 1$ ) with adding Pt-complex $(0.5 \mathrm{wt} \%$ based on PHMS content) were mixed by ball milling. The cross-linking process was carried in an oven

Received date: 2018-08-16; Modified date: 2018-09-12

Foundation item: Jiangxi Provincial Natural Science Foundation of China (20161BAB206131); Science and Technology Research Project of Jiangxi Provincial Education Department of China (GJJ180896, GJJ150928)

Biography: LI Jia-Ke (1973-), male, PhD, associate professor. E-mail: jiakeli.jci@163.com 
at $80^{\circ} \mathrm{C}$ for $10 \mathrm{~h}$.

The green bodies were pyrolyzed in an alumina tube furnace in Ar. The furnace temperature was raised at rate of $3{ }^{\circ} \mathrm{C} / \mathrm{min}$ and cooled at rate of $2^{\circ} \mathrm{C} / \mathrm{min}$. The temperature range of water injection was chosen at $500^{\circ} \mathrm{C}$ $800^{\circ} \mathrm{C}^{[13]}$. As temperature arrived at $500^{\circ} \mathrm{C}$, deionized water was injected into the furnace with rate of $0.25 \mathrm{~g} / \mathrm{min}$. When temperature arrived at $800^{\circ} \mathrm{C}$, water injection was stopped. The temperature was then raised to $900^{\circ} \mathrm{C}$ $1500^{\circ} \mathrm{C}$ for $60 \mathrm{~min}$, and then cooled down. Comparable experiments were carried out by pyrolysis of the green bodies without water injection using the same pyrolysis conditions.

\subsection{Characterization}

The etching process was performed on SiOC ceramics using HF solution $(20 \mathrm{wt} \%)$ until there was no distinct mass loss. Then, SiOC ceramics were rinsed with deionized water and dried at $120^{\circ} \mathrm{C}$. Phase compositions of the pyrolyzed samples were analyzed by XRD (D8 Advance). The step size was $0.03 \%$ with $\mathrm{Cu} \mathrm{K} \alpha$ radiation $(\lambda=$ $0.15406 \mathrm{~nm}$ ). FT-IR (Nicolet 8700) was recorded between $400 \mathrm{~cm}^{-1}$ and $4000 \mathrm{~cm}^{-1}$ wavenumber for SiOC ceramics analysis. Specific surface area and pore size distribution of the pyrolyzed samples were studied by BET method with a Quantachrome Autosorb-1 analyzer.
A field emission SEM (JSM-6700, JEOL) was used to characterize morphology of the pyrolyzed samples.

\section{Results and Discussion}

\subsection{Phase evolution}

Fig. 1 shows XRD patterns of SiOC ceramics pyrolyzed in $\mathrm{Ar}+\mathrm{H}_{2} \mathrm{O}$ at different temperatures before and after etching. For SiOC ceramic before etching (Fig.1(a)), XRD pattern at $900^{\circ} \mathrm{C}$ shows an amorphous structure with only the presence of the silica halo centered at $\sim 22.5^{\circ}$ and a weak carbon diffraction peak $\left(43.6^{\circ}\right)$. This means that phase separation in SiOC ceramic just starts to occur (compared Fig. 1(a) and Fig. 1(b)). When pyrolysis temperature is increased to $1000^{\circ} \mathrm{C}$, such tendency is more visible. At $1300^{\circ} \mathrm{C}$, new XRD peaks appear at $22.5^{\circ}, 36.3^{\circ}$ and $60.5^{\circ}$, indicating that $\mathrm{SiO}_{2}$ and $\mathrm{SiC}$ crystal start to form along with carbon formation. With the increase of pyrolysis temperature to $1500^{\circ} \mathrm{C}, \mathrm{XRD}$ peaks of $\mathrm{SiO}_{2}$ and $\mathrm{SiC}$ continue to strengthen.

Fig. 1(b) shows XRD patterns of SiOC ceramic pyrolyzed in $\mathrm{Ar}+\mathrm{H}_{2} \mathrm{O}$ at different temperatures after etching. Compared with XRD patterns before etching (Fig. 1(a)), $\mathrm{SiO}_{2}$ peaks disappear. At $1000^{\circ} \mathrm{C}$, the preceramic has obviously happened phase separation to form $\beta$-SiC and
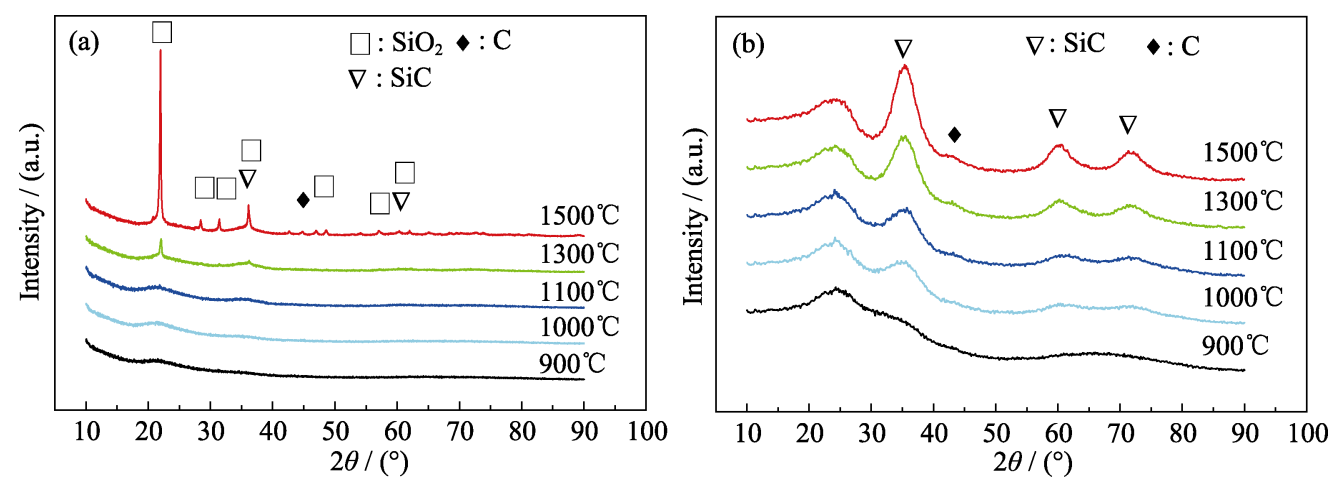

Fig. 1 XRD patterns of SiOC ceramics pyrolyzed in $\mathrm{Ar}+\mathrm{H}_{2} \mathrm{O}$ at different temperatures (a) Before etching; (b) After etching
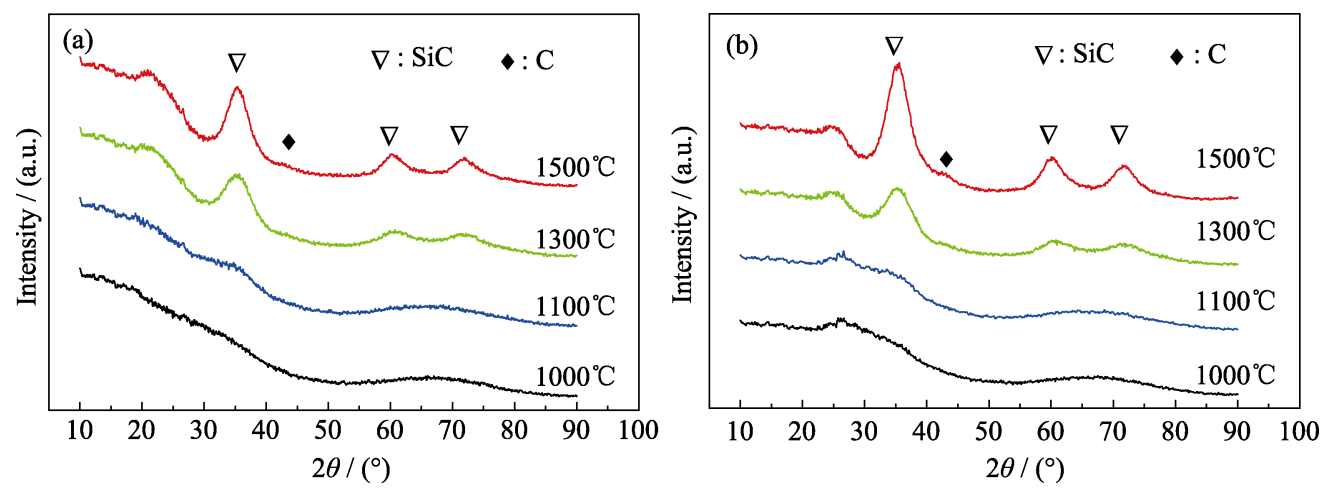

Fig. 2 XRD patterns of SiOC ceramics pyrolyzed in Ar at different temperatures

(a) Before etching; (b) After etching 
carbon. Intensities of XRD peaks for $\beta$-SiC and carbon increase after etching for the same sample, and obviously increase with the increase of pyrolysis temperature.

Compared with SiOC ceramics pyrolyzed only in Ar (see Fig. 2 (a)), the difference is that a completely amorphous structure is present at $1100^{\circ} \mathrm{C}$ pyrolysis temperature. At $1200^{\circ} \mathrm{C}$ and higher, the SiOC starts to undergo phase separation and forms $\mathrm{SiC}$, carbon, and $\mathrm{SiO}_{2}$ nanodomains (see Fig. 2 (b)). In the range of $1100^{\circ} \mathrm{C}-1500^{\circ} \mathrm{C}$, $\mathrm{SiO}_{2}$ crystal is not observed for the samples pyrolyzed in Ar.

Fig. 3 shows FT-IR spectra of the pyrolyzed SiOC ceramic in $\mathrm{Ar}+\mathrm{H}_{2} \mathrm{O}$ and $\mathrm{Ar}$ at $1300^{\circ} \mathrm{C}$ before and after etching. Intensity of $\mathrm{Si}-\mathrm{O}-\mathrm{Si}$ peak is much higher for the sample pyrolyzed in $\mathrm{Ar}+\mathrm{H}_{2} \mathrm{O}$ than those in Ar. This means that water vapor greatly favors $\mathrm{Si}-\mathrm{O}-\mathrm{Si}$ bonds formation. Moreover, it may be seen from Fig. 3 that the intensity of $\mathrm{Si}-\mathrm{O}-\mathrm{Si}$ peak obviously decreases after etching. This indicates that $\mathrm{Si}-\mathrm{O}-\mathrm{Si}$ bonds has been etched away by HF.

This difference can be understood as follows. For pyrolysis reactions in $\mathrm{Ar}, \mathrm{C}-\mathrm{H}, \mathrm{Si}-\mathrm{H}$ and $\mathrm{C}=\mathrm{C}$ bonds cleavage in organic groups occur, leading to $\mathrm{SiOC}$ ceramics consisting of amorphous $\mathrm{SiOC}$ with $\mathrm{Si}-\mathrm{O}, \mathrm{Si}-\mathrm{C}$ and $\mathrm{C}-\mathrm{C}$ bonds. For pyrolysis reactions in $\mathrm{Ar}+\mathrm{H}_{2} \mathrm{O}$, except for the above reactions, the reactions between organic groups and $\mathrm{H}_{2} \mathrm{O}$ produce $\mathrm{Si}-\mathrm{OH}$ bonds (Eq. (1)-(3)), and $\mathrm{Si}-\mathrm{OH}$ bonds are subsequently condensed into $\mathrm{Si}-\mathrm{O}-\mathrm{Si}$ through dehydrogenation reaction (Eq. (4) $)^{[14]}$. $\mathrm{SiO}_{2}$ nanodomains, $\mathrm{Si}-\mathrm{O}-\mathrm{Si}$ bonds and $\mathrm{SiO}_{2}$ nanocrystals in SiOC ceramic are etched away by HF (Eq. (5)), these will be helpful to increase specific surface area of SiOC porous ceramic.

$$
\begin{gathered}
\mathrm{Si}-\mathrm{H}+\mathrm{H}_{2} \mathrm{O}=\mathrm{Si}-\mathrm{OH}+\mathrm{H}_{2} \uparrow \\
\mathrm{Si}-\mathrm{CH}_{3}+\mathrm{H}_{2} \mathrm{O}=\mathrm{Si}-\mathrm{OH}+\mathrm{CH}_{4} \uparrow \\
\mathrm{Si}-\mathrm{CH}=\mathrm{CH}_{2}+\mathrm{H}_{2} \mathrm{O}=\mathrm{Si}-\mathrm{OH}+\mathrm{C}_{2} \mathrm{H}_{4} \uparrow \\
\mathrm{Si}-\mathrm{OH}+\mathrm{HO}-\mathrm{Si}=\mathrm{Si}-\mathrm{O}-\mathrm{Si}+\mathrm{H}_{2} \mathrm{O} \\
\mathrm{SiO}_{2} / \mathrm{Si}-\mathrm{O}-\mathrm{Si}+6 \mathrm{HF} \rightarrow \mathrm{H}_{2} \mathrm{SiF}_{6}+2 \mathrm{H}_{2} \mathrm{O}
\end{gathered}
$$

\subsection{Microstructure analysis}

Fig. 4 shows SEM cross section images of SiOC ceramic pyrolyzed at $1300^{\circ} \mathrm{C}$ in $\mathrm{Ar}+\mathrm{H}_{2} \mathrm{O}$ and in $\mathrm{Ar}$ before and after etching. The samples are dense and have no pores before etching (Fig. 4(a) and (c)). This means that the samples are sintered during pyrolysis, and the other samples also have dense structure which are pyrolyzed at $900^{\circ} \mathrm{C}-1500^{\circ} \mathrm{C}$. After etching, the samples have porous structure (Fig. 4(b) and (d)). These pores are left behind after phase separated $\mathrm{SiO}_{2}$ nanodomains/crystals and $\mathrm{Si}-\mathrm{O}-\mathrm{Si}$ bonds are etched away by HF (Eq. (5)). Moreover, it may be seen from Fig. 4(b) and (d), the sample pyrolyzed in $\mathrm{Ar}+\mathrm{H}_{2} \mathrm{O}$ owns much more porosity than that of the sample pyrolyzed in Ar. These are due to the fact that water may react with the precursors and promote their phase separation at low temperature (Eq. (1-4)), produce

$\mathrm{SiO}_{2}$ nanodomains, $\mathrm{Si}-\mathrm{O}-\mathrm{Si}$ bonds and $\mathrm{SiO}_{2}$ nanocrystals, so the samples own much more porosity after etching.

\subsection{Specific surface area and pore size}

BET adsorption-desorption isotherms of SiOC ceramics pyrolyzed in $\mathrm{Ar}+\mathrm{H}_{2} \mathrm{O}$ and in $\mathrm{Ar}$ at $1300^{\circ} \mathrm{C}$ after etching are shown in Fig. 5. The hysteresis loops are very narrow and adsorption-desorption branches almost overlap with each other, and there is a plateau at higher relative pressure region of the isotherms. These indicate that $\mathrm{SiOC}$ ceramics contain narrow micro-/meso-pores. The insets in Fig. 5(a) and (b) show that pore size distribution is $2 \mathrm{~nm}$ $10 \mathrm{~nm}$ and $2 \mathrm{~nm}-6 \mathrm{~nm}$, respectively. In addition, it can be seen from Fig. 5(a) and (b) that $\mathrm{N}_{2}$ maximum adsorbed volume and pore volume for the sample pyrolyzed in $\mathrm{Ar}+\mathrm{H}_{2} \mathrm{O}$ is higher than that of the sample pyrolyzed in $\mathrm{Ar}$. Cumulative and interval specific surface area for SiOC are shown in Fig. 6. It may be seen from Fig. 6(a) and (b) that specific surface area arrives at $1845.50 \mathrm{~m}^{2} / \mathrm{g}$ for SiOC ceramics pyrolyzed in $\mathrm{Ar}+\mathrm{H}_{2} \mathrm{O}$, and it is 2.91 times than that of SiOC pyrolyzed in Ar.

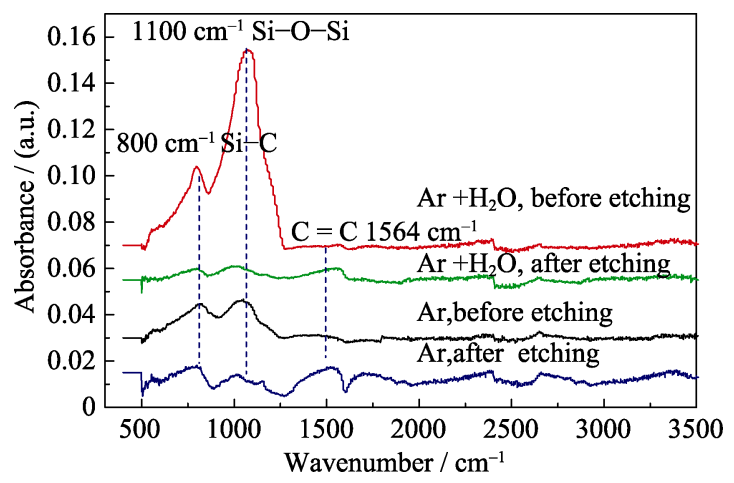

Fig. 3 FT-IR spectra of SiOC ceramics pyrolyzed in $\mathrm{Ar}+\mathrm{H}_{2} \mathrm{O}$ and $\mathrm{Ar}$ at $1300^{\circ} \mathrm{C}$ before and after etching

(a)

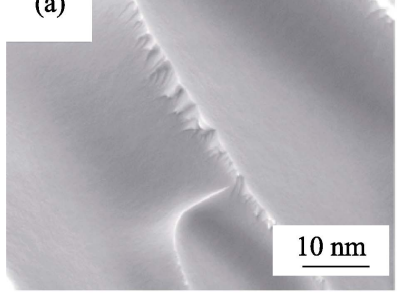

(c)

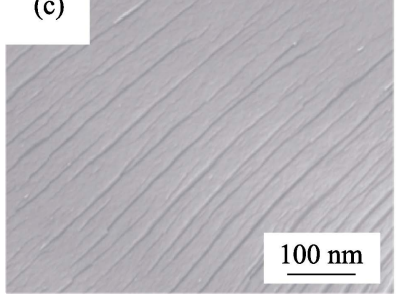

Fig. 4 SEM cross section images of SiOC pyrolyzed at $1300^{\circ} \mathrm{C}$ in $\mathrm{Ar}+\mathrm{H}_{2} \mathrm{O}$ before (a) and after (b) etching, in $\mathrm{Ar}$ before (c) and after (d) etching

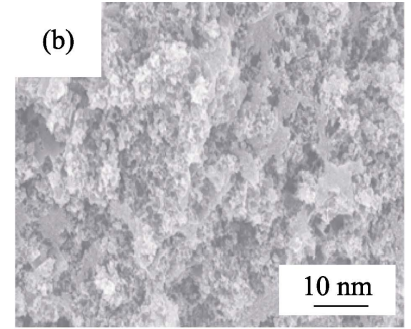

(d)

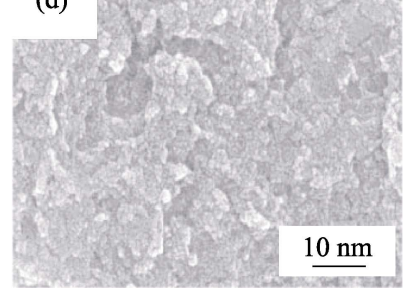



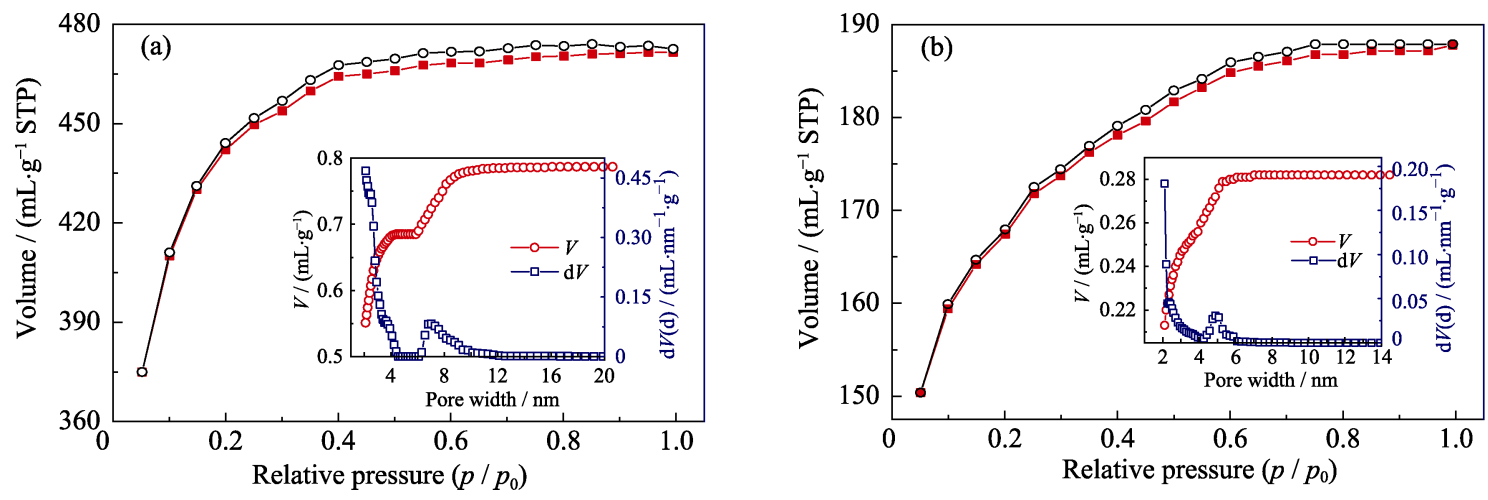

Fig. $5 \quad \mathrm{~N}_{2}$ adsorption (solid symbols) and desorption (open symbols) isotherms for the samples obtained from $\mathrm{SiOC}$ ceramics pyrolyzed in (a) $\mathrm{Ar}+\mathrm{H}_{2} \mathrm{O}$ and (b) Ar at $1300^{\circ} \mathrm{C}$ after etching

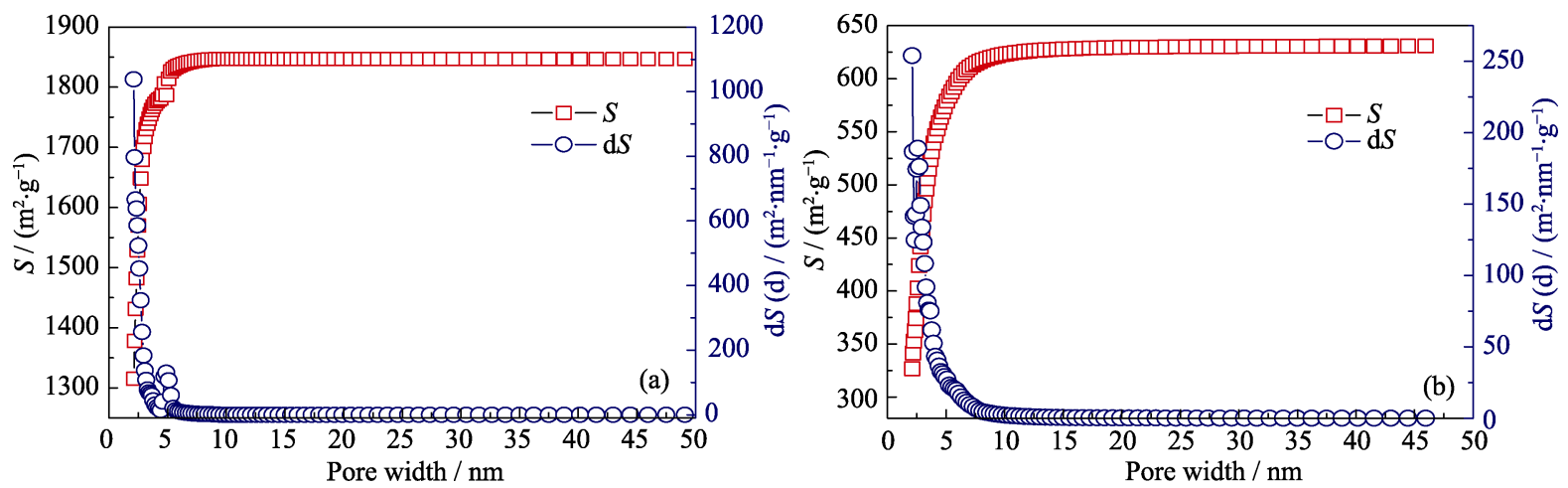

Fig. 6 Cumulative specific surface area $(S)$, interval specific surface area (dS) and pore size distribution (PSD) for SiOC ceramics pyrolyzed in $\mathrm{Ar}+\mathrm{H}_{2} \mathrm{O}$ (a) and in $\mathrm{Ar}(\mathrm{b})$ at $1300^{\circ} \mathrm{C}$ after etching

Table 1 BET results of SiOC ceramics after etching with different pyrolysis temperatures in $\mathrm{Ar}$ and $\mathrm{Ar}+\mathrm{H}_{2} \mathrm{O}$

\begin{tabular}{ccccccc}
\hline \multirow{2}{*}{ Temperature $/{ }^{\circ} \mathrm{C}$} & \multicolumn{2}{c}{ Specific surface $\mathrm{area} /\left(\mathrm{m}^{2} \cdot \mathrm{g}^{-1}\right)$} & \multicolumn{2}{c}{ Average pore size $/ \mathrm{nm}$} & \multicolumn{2}{c}{ Pore volume $\left./\left(\mathrm{cm}^{3} \cdot \mathrm{g}^{-1}\right)\right)$} \\
\cline { 2 - 7 } & $\mathrm{Ar}$ & $\mathrm{Ar}+\mathrm{H}_{2} \mathrm{O}$ & $\mathrm{Ar}$ & $\mathrm{Ar}+\mathrm{H}_{2} \mathrm{O}$ & $\mathrm{Ar}$ & $\mathrm{Ar}+\mathrm{H}_{2} \mathrm{O}$ \\
\hline 900 & - & 58.6 & - & 2.05 & - & 0.105 \\
1100 & - & 435.23 & - & 2.16 & - & 0.142 \\
1200 & 53.65 & 654.16 & 1.43 & 2.23 & 0.015 & 0.202 \\
1300 & 635.13 & 1845.50 & 2.25 & 2.83 & 0.282 & 0.788 \\
1400 & 632.24 & 1817.20 & 2.18 & 2.75 & 0.286 & 0.764 \\
1500 & 633.52 & 1805.60 & 2.15 & 2.77 & 0.288 & 0.756 \\
\hline
\end{tabular}

Note: The samples pyrolyzed in $\mathrm{Ar}$ at $900^{\circ} \mathrm{C}$ and $1100^{\circ} \mathrm{C}$ are not listed in Table 1, because they are fully dense before and after $\mathrm{HF}$ etching.

BET results of SiOC ceramics pyrolyzed at different temperatures after etching are shown in Table 1. For $\mathrm{SiOC}$ ceramics pyrolyzed in $\mathrm{Ar}+\mathrm{H}_{2} \mathrm{O}$, at $900^{\circ} \mathrm{C}$, $\mathrm{SiOC}$ shows a little porous after etching. Moreover, at the same temperature, the samples pyrolyzed in $\mathrm{Ar}+\mathrm{H}_{2} \mathrm{O}$ have higher specific surface area than those of the samples pyrolyzed in Ar. These results are consistent with XRD, FT-IR and SEM analysis.

\section{Conclusions}

SiOC porous ceramics with high specific surface area and micro-/meso-pores are prepared by pyrolysis of the precursors in $\mathrm{Ar}+\mathrm{H}_{2} \mathrm{O}$ and subsequent HF etching. Water vapor reacts with organic groups to promote phase separation at $500^{\circ} \mathrm{C}-800^{\circ} \mathrm{C}$ and produces $\mathrm{Si}-\mathrm{O}-\mathrm{Si}$ bonds. Above $1100^{\circ} \mathrm{C}, \mathrm{Si}-\mathrm{O}-\mathrm{Si}$ bonds gradually crystallize into $\mathrm{SiO}_{2}$ nanocrystals. The $\mathrm{Si}-\mathrm{O}-\mathrm{Si}$ bonds, $\mathrm{SiO}_{2}$ nanodomains and $\mathrm{SiO}_{2}$ nanocrystals in $\mathrm{SiOC}$ ceramic can be etched away by HF and leave behind micro-/ meso-pores. Therefore, SiOC porous ceramics shows higher specific surface area than those of pyrolyzed only in Ar. A maximum specific surface area of $1845.50 \mathrm{~m}^{2} / \mathrm{g}$, average pore size of $2.83 \mathrm{~nm}$, pore volume of $0.788 \mathrm{~cm}^{3} / \mathrm{g}$ can be obtained at pyrolysis temperature of $1300^{\circ} \mathrm{C}$ in $\mathrm{Ar}+\mathrm{H}_{2} \mathrm{O}$. 


\section{References:}

[1] IONESCU E, KLEEBE H J, RIEDEL R. Silicon-containing polymerderived ceramic nanocomposites (PDC-NCs): preparative approaches and properties. Chem. Soc. Rev., 2012, 41(15): 50325052.

[2] FENG Y, LAI S Y, YANG L, et al. Polymer-derived porous $\mathrm{Bi}_{2} \mathrm{WO}_{6} / \mathrm{SiC}(\mathrm{O})$ ceramic nanocomposites with high photodegradation efficiency towards Rhodamine B. Ceram. Int., 2018, 44(7): 8562-8569.

[3] COLOMBO P. Conventional and novel processing methods for cellular ceramics. Philos. Trans., 2006, 364(1838): 109-124.

[4] YAN X J, SAHIMI M, TSOTSIS T T. Fabrication of high-surface area nanoporous $\mathrm{SiOC}$ ceramics using preceramic polymer precursors and a sacrificial template: precursor effects. Micropor. Mesopor. Mat., 2017, 241: 338-345.

[5] VAKIFAHMETOGLU C, COLOMBO P. A direct method for the fabrication of macro-porous SiOC ceramics from preceramic polymers. Adv. Eng. Mater., 2008, 10(3): 256-259.

[6] DIBANDJO P, DIRE S, BABONNEAU F, et al. Influence of the polymer architecture on the high temperature behavior of SiCO glasses: a comparison between linear- and cyclic-derived precursors. J. Non-Cryst. Solids, 2010, 356(3): 132-140.
[7] FORTUNIAK W, POSPIECH P, MIZERSKA U, et al. Generation of meso- and microporous structures by pyrolysis of polysiloxane microspheres and by HF etching of SiOC microspheres. Ceram. Int., 2018, 44(1): 374-383.

[8] VAKIFAHMETOGLU C, PRESSER V, YEON S H, et al. Enhanced hydrogen and methane gas storage of silicon oxycarbide derived carbon. Micropor. Mesopor. Mat., 2011, 144(1): 105-112.

[9] SORARU G D, PENA-ALONSO R, LEONI M. C-rich micro/ mesoporous $\mathrm{Si}(\mathrm{B}) \mathrm{OC}$ : in situ diffraction analysis of the HF etching process. Micropor. Mesopor. Mat., 2013, 172: 125-130.

[10] XU T H, MA Q S, CHEN Z H. High-temperature behavior of silicon oxycarbide glasses in air environment. Ceram. Int., 2011, 37(7): 2555-2559.

[11] SAHA A, RAJ R. Crystallization maps for SiCO amorphous ceramics. J. Am. Ceram. Soc., 2007, 90(2): 578-583.

[12] LI J K, LU K, LIN T S, et al. Preparation of micro-/meso porous SiOC bulk ceramics. J. Am. Ceram. Soc., 2015, 98(6): 1753-1761.

[13] WU J Q, LI Y M, CHEN L M, et al. Simple fabrication of micro/ nano-porous SiOC foam from polysiloxane. J. Mater. Chem., 2012, 22(14): 6542-6545.

[14] LIANG T, LI Y L, SU D, et al. Silicon oxycarbide ceramics with reduced carbon by pyrolysis of polysiloxanes in water vapor. J. Eur. Ceram. Soc., 2010, 30(12): 2677-2682.

\title{
低温分相法制备高比表面积微/介孔 SiOC 陶瓷
}

\author{
李家科，韩效奇，刘欣，王艳香，郭平春，杨志胜 \\ (景德镇陶瓷大学材料科学与工程学院, 景德镇 333403)
}

摘 要: 以含氢聚硅氧烷(PHMS)、四甲基四乙烯基环四硅氧烷 $\left(\mathrm{D}_{4}{ }^{\mathrm{vi}}\right)$ 和铂络合物为原料, 采用热交联合成交联体, 通 过水蒸汽辅助热解促进前驱体低温分相及后续 HF 对 SiOC 陶瓷侵蚀基础上，获得高比表面积微/介孔 $\mathrm{SiOC}$ 陶瓷。 采用 XRD、FT-IR、SEM 和 BET 等测试技术对试样的物相组成、化学键、微观结构、比表面积和孔径分布等进行 了表征。实验结果表明, 水蒸气能够促进前驱体低温分相, 使 $\mathrm{SiOC}$ 陶瓷中生成 $\mathrm{Si}-\mathrm{O}-\mathrm{Si}$ 键、 $\mathrm{SiO}_{2}$ 纳米畴和 $\mathrm{SiO}_{2}$ 纳米晶, 这些可以作为造孔剂而被 $\mathrm{HF}$ 侵蚀, 从而提高了 $\mathrm{SiOC}$ 陶瓷的比表面积。在热解温度 $1300^{\circ} \mathrm{C}$ 条件下, 微/介 孔 $\mathrm{SiOC}$ 陶瓷具有最大比表面积 $1845.5 \mathrm{~m}^{2} / \mathrm{g}$, 孔径分布 $2.0 \sim 10 \mathrm{~nm}$ 。

关 键 词: 微/介孔 SiOC 陶瓷; 低温分相; 物相组成; 微观结构; 侵蚀 中图分类号: TQ174 文献标识码: A 